\title{
A Study on Solid Waste Management Practices by Rural Women in Medak, Telangana State
}

\author{
B. Spandana* and B. Jamuna Rani
}

\begin{abstract}
Department of Home Science Extension and Communication Management, College of Community Science, Professor Jayashankar Telangana State Agricultural University, Hyderabad, Telangana, India
\end{abstract}

*Corresponding author

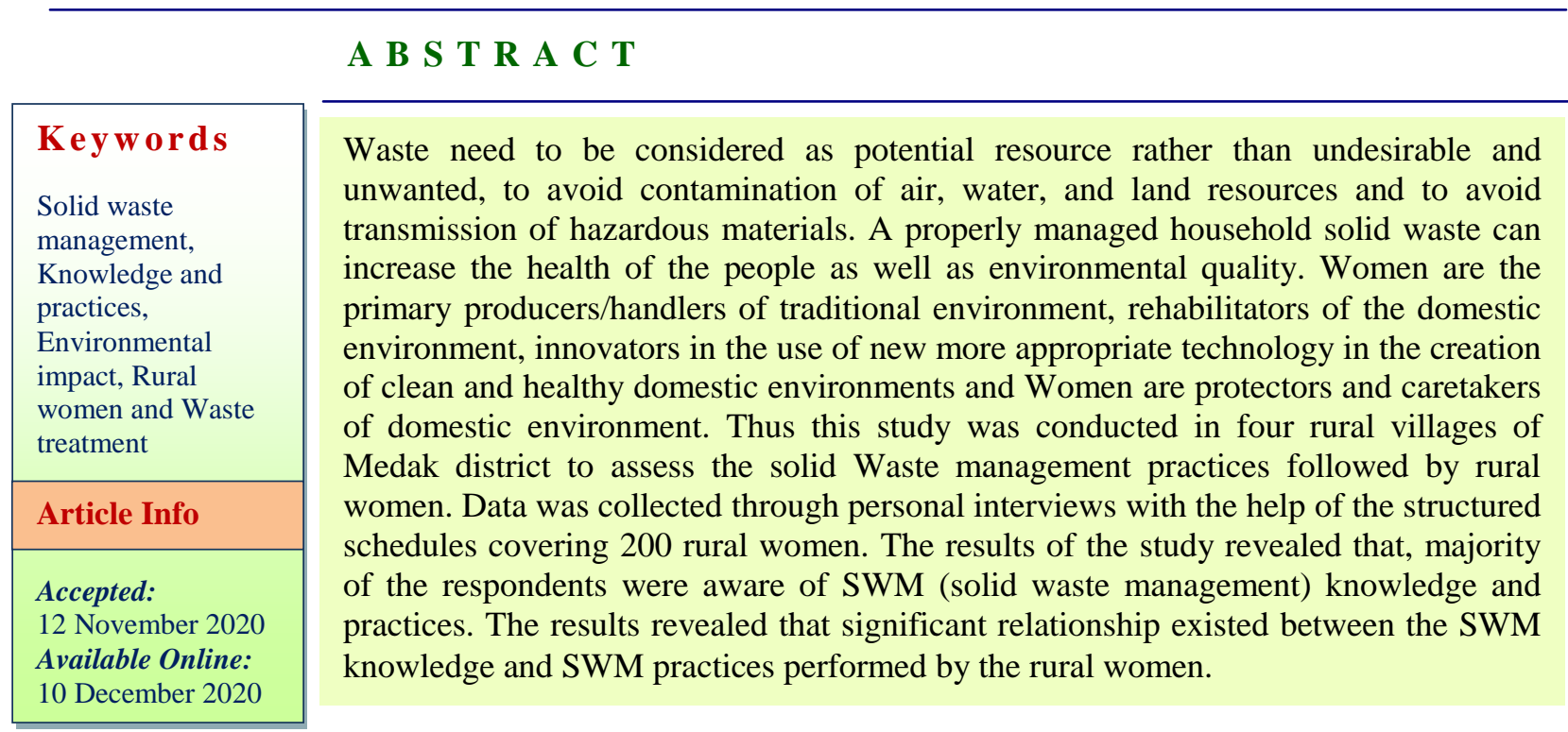

\section{Introduction}

Waste management is the collection, treatment, and disposal of solid material that is discarded because it has served its purpose or is no longer useful. Improper disposal of waste can be created unsanitary conditions, which lead to environment pollution and have the effect on human health. India is predominantly a rural country. As per the 2011 Census, 68.8 per cent of country's population and 72.4 per cent of workforce resided in rural areas. Total per day waste generation in India was 143572 tonnes as on 31st January 2018. The top 10 States/UTs with respect to per day waste generation were Maharashtra, Tamil Nadu, Uttar Pradesh, NCT of Delhi, Gujarat, Karnataka, West Bengal, Telangana, Rajasthan and Madhya Pradesh. The per day waste generation in Telangana, was 7371 tonnes. These top 10 States/UTs accounted for $77.96 \%$ of the total 
per day waste generation in India as a whole. (Source: Ministry of Housing and Urban Affairs)

Population explosion, technological advancement, improved life style of the people, results in increased generation of solid wastes in urban as well as rural areas of the country. The solid waste from rural areas is biodegradable nature where as in urban areas contains more non-biodegradable components like plastics \& packaging.

Improper disposal of waste can pose major public health threats and environmental issues. Due to the location of the dumpsite closer to their settlements people suffered from malaria, chest pains, diarrhea and cholera (Va et al., 2019). A major environmental concern is the release of gas by decomposing garbage and these gasses enhance greenhouse gas effect and "global warming". (Alam, 2013)

Waste management in India is a challenge due to increased population. Government of India initiated swach bharat mission (SBM) or swachh bharat abhiyan (SBA) or clean India mission to eliminate open defecation and improve solid waste management (SWM) in urban and rural areas. Because properly managed effective waste management programme increases the health and environmental quality of the country.

\section{Materials and Methods}

The present study was conducted to analyze the waste management practices by the rural women. The selected study area is purposive based on the implementation of the Govt. program Swachaa bharat abhiyan which focus on providing interventions for the safe management of solid and liquid waste in the villages under study. Exploratory research design was used for the study. This study was conducted in four villages of Medak district, Telangana state. A total of 200 rural households from four villages were selected by using random sampling method. The data from the respondents was collected through personal interviews with the help of the structured schedules and were analyzed using standard statistical tools.

Rajkumar Joshi and Sirajuddin Ahmed (2016) concluded that. Lack of awareness, inappropriate technical knowledge, inadequate funding, unaccountability, implementation of legislation and policies were major reasons for the failure of MSWM (Municipal solid waste management). They also suggested that Installation of decentralized solid waste processing units in metropolitan cities/towns and development of formal recycling industry sector is the need of the hour in developing countries like India.

\section{Results and Discussion}

Age: As indicated in the Table 1, most $(79.50 \%)$ of the respondents belonged to young age followed by middle age (20.50\%).

Education: Out of the total respondents, majority (35.50) percent studied up to secondary level, followed by primary school $(30.00 \%)$, illiterates $(16.50 \%)$, intermediate $(13.50 \%)$ and very few $(4.50 \%)$ were had graduation and above. Ramos (2016) found that, educational attainment was significantly related to the waste storage and disposal of the knowledge in solid waste management.

Marital status: Out of the total respondents, 84.00 percent of the respondents were married women, only $16.00 \%$ were unmarried, this may be due to that they belong to young age.

Family type: From table 1, it can be indicated that majority $(81.00 \%)$ of the respondents belonged to nuclear family and few (19.00\%) respondents belonged to joint family. 
Occupation: As indicated in the Table 1, 39.00 percent of the respondents occupation were agricultural laborers, followed by 32.00 percent was agriculture, 17.00 percent respondents were tailors and 12.00 percent of the respondents had other works as their occupation such as petty shops, vegetable vendors and Bangle stores.

\section{Solid Waste management practices by rural women}

Solid waste management has become very important in rural areas too. Govt. of India is focusing on the Solid Waste management in rural areas to dispose of household waste in a scientifically sensible manner, so that properly managed garbage in rural areas can increase quality of life of the people. With the introduction of Swachh Bharat mission in India, the initiatives by local Gram Panchayats (GPs) in the villages under study are taking responsibility for creation of awareness on scientific methods of waste disposal, garbage collection and disposal in a proper manner.

The members of the Gram Panchayat made necessary arrangements to educate and create awareness to the rural women on the waste management practices. Stringent measures were taken to collect the house hold waste in regular intervals in the form of dry and wet waste. The local authorities also distributed dustbins to every household.

Table 2, clearly showed that, majority $(75.00 \%, 87.50 \%)$ of the respondents were aware on practices of solid waste management and had knowledge on segregation of wet and dry waste. A percentage of 81.00 respondents were conscious of biodegradable waste but 41.00 percent respondents aware of nonbiodegradable waste. Out of total respondents, 60.00 percent rural women were aware about
3R(Reduce, Reuse, Recycle). A great majority $(87.00 \%)$ indicated that biodegradable waste can be used as vermin compost meanwhile half $(51.00 \%)$ of the respondents had awareness of environmental impact due to improper waste management, half of the respondents (55.00) had awareness on health and 43.00 percent respondents had agreed that proper waste management lead to economic benefits.

Warunasinghe (2016) found in his study that, only $2 \%$ of the respondents did not have much concern about the health impact of improper waste management. The results also showed that $26 \%$ of the households were not aware of waste recycling, reuse $\&$ reduction.

The above table 3, presented solid waste management practices by the rural women. Out of total respondents, almost all the respondents $(93.33 \%)$ had dustbin at their home. Because dustbin is compulsory as swachaa bharat abhiyan programme is under implementation in those villages. Most of the respondents $(83.00 \%)$ were Segregating dry and wet waste. Few respondents $(24.00 \%)$ were using the kitchen waste for pet animals such as cattle, hen etc while 87.50 percent were preparing manure pits with the wet waste.

Only 27.00 percent covered or had closed dustbins, this is because they were using waste buckets, tins as dustbins. As shown in the table 3, majority $(69.00 \%)$ of the respondents were burning household waste (sanitary pads, polythene covers, leaves etc) at their backyard and 80.00 percent of the respondents were reusing/recycling household waste such as old buckets as dustbins. As shown in the table, 47.00 percent of the respondents were using bio-waste for preparation of vermicompost and 66.00 percent were using kitchen waste for feeding their cattle. 
Table.1 General profile of the respondents $n=200$

\begin{tabular}{|c|c|c|c|}
\hline S.No & Profile characteristics & Frequency $(\mathbf{F})$ & Percentage (\%) \\
\hline & Age of the respondents & & \\
\hline 1 & $18-35$ (Young) & 159 & 79.50 \\
\hline \multirow[t]{2}{*}{2} & 36-55(Middle) & 41 & 20.50 \\
\hline & Education levels of the respondents & & \\
\hline 3 & Illiterate & 33 & 16.50 \\
\hline 4 & Primary education & 60 & 30.00 \\
\hline 5 & Secondary education & 71 & 35.50 \\
\hline 6 & Intermediate/Diploma & 27 & 13.50 \\
\hline \multirow[t]{2}{*}{7} & Degree and above & 9 & 4.50 \\
\hline & Marital status & & \\
\hline 1 & Unmarried & 32 & 16.00 \\
\hline \multirow[t]{2}{*}{2} & Married & 168 & 84.00 \\
\hline & Family type & & \\
\hline 8 & Nuclear family & 162 & 81.00 \\
\hline \multirow[t]{2}{*}{9} & Joint family & 38 & 19.00 \\
\hline & Occupation & & \\
\hline 10 & Agriculture & 64 & 32.00 \\
\hline 11 & Agricultural labour & 78 & 39.00 \\
\hline 12 & Tailoring & 34 & 17.00 \\
\hline 13 & $\begin{array}{l}\text { Other Occupation } \\
\text { (Petty shops } \\
\text { Vegetable vendors } \\
\text { Bangle stores) }\end{array}$ & 24 & 12.00 \\
\hline
\end{tabular}

Table.2 Rural women knowledge on solid Waste management n=200

\begin{tabular}{|c|c|c|c|}
\hline S.no & Statement & Frequency $(F)$ & $\begin{array}{l}\text { Percentage } \\
(\%)\end{array}$ \\
\hline 1 & Awareness on solid waste management & 150 & 75.00 \\
\hline 2 & Segregation of wet and dry waste & 175 & 87.50 \\
\hline 3 & $\begin{array}{l}\text { Kitchen waste, crop waste, and cattle dung are } \\
\text { biodegradable waste }\end{array}$ & 162 & 81.00 \\
\hline 4 & $\begin{array}{l}\text { Plastic, polythene, glass, metal, rubber are non- } \\
\text { biodegradable waste }\end{array}$ & 82 & 41.00 \\
\hline 5 & Awareness on 3R (Reduce, Reuse, Recycle) & 120 & 60.00 \\
\hline 6 & Biodegradable waste should be used for vermicompost & 174 & 87.00 \\
\hline 7 & Awareness on environmental impact of solid waste & 102 & 51.00 \\
\hline 8 & $\begin{array}{l}\text { Awareness on health impact of solid waste (burning of } \\
\text { plastic, polythene, rubber etc.) }\end{array}$ & 110 & 55.00 \\
\hline 9 & $\begin{array}{l}\text { Proper waste management can lead to economic } \\
\text { benefits }\end{array}$ & 86 & 43.00 \\
\hline
\end{tabular}


Table.3 Rural women Practices on solid Waste management $n=200$

\begin{tabular}{|l|l|c|c|}
\hline S.no & Statement & $\begin{array}{l}\text { Frequency } \\
(\mathbf{F})\end{array}$ & Percentage (\%) \\
\hline $\mathbf{1}$ & Dustbin at home & 186 & 93.00 \\
\hline $\mathbf{2}$ & Segregation of dry and wet waste & 166 & 83.00 \\
\hline $\mathbf{3}$ & Kitchen waste for pet animals & 178 & 24.00 \\
\hline $\mathbf{4}$ & Waste in manure pit & 54 & 87.50 \\
\hline $\mathbf{5}$ & keeping the waste or Dustbin covered & 138 & 27.00 \\
\hline $\mathbf{6}$ & Burning the waste at home eg: polythene & 160 & 89.00 \\
\hline $\mathbf{7}$ & $\begin{array}{l}\text { Reuse/recycling non-biodegradable waste eg- } \\
\text { plastic, polythene etc }\end{array}$ & 94 & 47.00 \\
\hline $\mathbf{8}$ & Vermi compost using bio-waste & 132 & 66.00 \\
\hline $\mathbf{9}$ & Kitchen waste used for cattle feed & & \\
\hline
\end{tabular}

Table.4 Correlation analysis between SWM knowledge and SWM practices by the rural women

\begin{tabular}{|l|l|l|}
\hline S.No & Solid waste management & Practice (r value) \\
\hline $\mathbf{1}$ & Knowledge & $.422^{* *}$ \\
\hline$* *$ Correlation is significant at the 0.01 level (2-tailed)
\end{tabular}

Table 4 shows the significant relationship between the SWM knowledge and SWM practices by the rural women. The results revealed that there is significant relationship exists between SWM knowledge and SWM practices with $r$ value of. 422 , $p$-value $=.000$. This implies that level of Solid waste management Knowledge had influenced respondents towards solid waste management practices. Laor et al., (2017) results also showed that there was a positive correlation relationship between MSW knowledge and practices.

In conclusion the solid waste management is the major challenge to establish balance between environment and development and therefore creation of favourable social and political environments should be the concern of the natives and the local officials for creating awareness on environmental protection. After thorough analysis of the results based on the findings of the study, it can be concluded that majority of the respondent's belonged to young age and unmarried. Most of the respondents had knowledge on solid waste management due to implementation of the program Swachacha Bharat Abhiyan in the villages. The respondents who had good knowledge also had a good level of practice. The results of the study revealed that that there is significant relationship exists between SWM knowledge and SWM practices.

\section{Recommendations}

Continuous awareness programmes and monitoring to be implemented to sustain the household waste management in rural areas.

Employment opportunities can be generated to the rural poor by adopting innovative initiatives in solid waste management.

\section{References}

Alam Pervez and Ahmade Kafeel. 2013. Impact of Solid Waste on Health and the Environment. Special Issue of 
International Journal of Sustainable Development and Green Economics. 2 (1): 2315-4721.

https://community.data.gov.in/top-10-statesuts-with-respect-to-per-day-wastegeneration-as-on-31st-jan-2018/

Laor Pussadee, Suma Yanasinee, Keawdounglek Vivat, Anuttara Hongtong, Tawatchai Apidechkul and Nittaya Pasukphun. 2017. Knowledge, attitude and practice of municipal solid waste management among highland residents in Northern Thailand. Journal of Health Research. 32(2).

Rajkumar Joshi and Sirajuddin Ahmed (2016). Status and challenges of municipal solid waste management in India: A review. Environmental Chemistry, Pollution \& Waste Management.

https://doi.org/10.1080/23311843.2016. 1139434
Ramos A Jose Niňo and Pecajas Elvira S. 2016. Knowledge, attitudes and practices in solid waste management among the secondary schools in the division of leyte. International journal of engineering sciences \& research technology. 5(7).

Va, Ndukwe., Mu, Uzoegbu., Os, Ndukwe And An, Agibe. 2019. Environmental and Health Impact of Solid Waste Disposal in Umuahia and Environs, Southeast, Nigeria. Journal of Applied Sciences and Environmental Management. 23 (9)

Warunasinghe W.A.A.I and Yapa, P.I. 2016. A survey on household solid waste management (SWM) with special reference to a peri-urban area (Kottawa) in Colombo. International Conference of Sabaragamuwa University of Sri Lanka. $257-260$.

\section{How to cite this article:}

Spandana, B. and Jamuna Rani, B. 2020. A Study on Solid Waste Management Practices by Rural Women in Medak, Telangana State. Int.J.Curr.Microbiol.App.Sci. 9(12): 1569-1574. doi: https://doi.org/10.20546/ijcmas.2020.912.185 